\title{
Waste incineration in Swedish municipal energy systems
}

\author{
K. Holmgren \\ Linköping Institute of Technology, Linköping, Sweden
}

\begin{abstract}
Waste is widely used as a fuel in the Swedish district heating (DH) systems, thereby linking waste management and the energy system. This paper summarizes earlier studies by the author on the role of waste as a fuel in DH systems. The method used is case studies of three Swedish municipalities that utilise waste in their DH systems. Economic optimisations of the DH systems are made using the linear programming model MODEST, and environmental effects in terms of carbon dioxide emissions are assessed. It is economically advantageous to use waste as a fuel due to regulations in the waste management sector and high taxes on fossil fuels. There can be a conflict between combined heat and power (CHP) production in DH systems and waste incineration, since the latter can remove the heat sink for other CHP plants in combination with low electrical efficiency in waste incineration plants. CHP is the main measure to decrease carbon dioxide emissions in DH systems on the assumption that locally produced electricity replaces electricity in coal condensing plants. It can be difficult to design policy instruments for waste incineration due to conflicting goals for waste management and energy systems. To put costs on environmental effects, so called external costs, is one way to include them but the method has drawbacks, for example the limited range of environmental effects included. Comparing the energy efficiency of material recovery and energy recovery from waste incineration is one way to assess the resource efficiency of the waste treatment methods.

Keywords: district heating, energy recovery, combined heat and power, material recovery, waste incineration, modelling, policy instruments, waste management.
\end{abstract}




\section{Introduction}

Waste management and energy systems are closely linked in Sweden, since heat from waste incineration is an important contributor to the overall supply in the district heating (DH) networks. Regulations in one sector have impacts in the other. This paper will summarize findings from earlier studies by the author of the role of waste incineration in the Swedish district heating systems, including the following: the profitability of using waste as a fuel for energy utilities; investigating the role of $\mathrm{DH}$ system as a user of various kinds of waste heat, i.e. from industries, waste incineration, and combined heat and power (CHP); analysis of some policy instruments affecting the waste management and DH sector; comparing energy and material recovery from the point of view of energy efficiency; and internalising the external costs in a DH system with the emphasis on waste incineration in order to obtain a socio-economic perspective on using waste as a fuel.

\section{Methodology}

The method used is case studies, where three Swedish municipalities of various sizes were analysed, all with the main common feature, viz. that they use waste as a fuel for DH production. A model of the features of the DH system, such as conversion units, heat demand, and fuels used, was built in an optimisation tool called MODEST (Model for Optimisation of Dynamic Energy Systems with Time-dependent components and boundary conditions) (Henning [1]). It is a linear programming model that minimises the cost of supplying heat demand during the analysed period. Electricity sales are treated as income. Scenarios are chosen to reflect issues to be investigated. After modelling, the results were analysed, and have been presented and discussed with the utilities operating the DH systems.

\section{Waste management with emphasis on waste incineration}

The EU's waste policy is founded on the waste hierarchy, described in the Sixth Environmental Action Programme from the European Commission [2] and states that first comes waste prevention, then recovery (reuse, material and energy recovery where material recovery, including biological treatment is preferred to energy recovery) and finally disposal, where landfill and waste incineration without energy recovery are included. Swedish waste policy is based upon this hierarchy. The strategy for Swedish waste management can be found in (Swedish Environmental Protection Agency [3]).

Energy recovery by waste incineration is the treatment method for almost half of all municipal waste today, as can be seen in Figure 1 (Swedish Association of Waste Management [4]). 


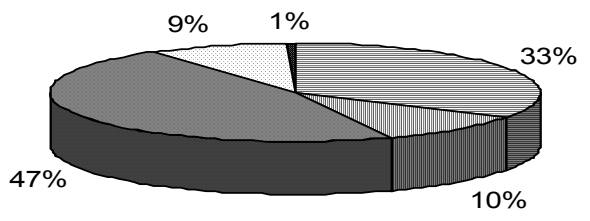

Figure 1: Treatment methods of municipal waste in 2004, total amount 4.2 million tons.

\subsection{Waste as a fuel in district heating systems}

In Sweden, with extensive district heating (DH) systems that supply $40 \%$ of the total heating demand of buildings and premises, heat supply from waste incineration has a substantial share of the total DH supply of about $15 \%$ (Swedish Energy Agency [5]). Today, there are 29 waste incineration facilities in Sweden, including 14 hot water boilers and 15 combined heat and power (CHP) plants producing about 8.6 TWh heat and 0.74 TWh electricity (Swedish Association of Waste Management [4]). In 2004, these facilities treated about 1.95 million tons of municipal waste and 1.2 million tons of other waste, mainly from the manufacturing industry.

Capacity for waste incineration is currently increasing and is forecast to expand from 2.8 Mton in 2002 to 4.9 Mton in 2008, if all planned projects are carried out (Swedish Association of Waste Management [6]) resulting in a total of 40 waste incineration plants. Despite these investments there will still be a lack of treatment capacity. Quantities of waste are also increasing, between 1985 and the present by approximately $2-3 \%$ per year. If this trend is not broken, additional waste treatment capacity will also be needed after 2008 .

CHP is recognised as one measure to decrease carbon dioxide emissions in the European Union. A directive is in place that aims to create a framework for promoting cogeneration [7]. However, electricity production in the Swedish DH networks is low. The total delivered heat in 2003 was $47.5 \mathrm{TWh}$, and the amount of electricity produced in the DH system was $6.0 \mathrm{TWh}$ [8]. There may be a conflict between CHP and waste incineration, since waste-fired CHP plants have low electrical efficiency. This is due to the many impurities in the fuel; the temperature of the steam in the boiler cannot exceed $400^{\circ} \mathrm{C}$ without entailing high maintenance costs due to corrosion. However, electricity production at waste incineration plants is forecast to increase from 0.7 to $1.7 \mathrm{TWh}$ between 2002 and 2010 (Swedish District Heating Association [9]). The study does not clarify the reason for the increase in electricity production at waste fired CHP 
plants, but it is reasonable to believe that it is a result of the higher electricity prices that are anticipated when Swedish electricity prices are harmonized with those in continental Europe (Trygg and Karlsson [10]). A proposed tax on incinerated waste, which is designed to promote CHP production, is probably also a factor (Ministry of Finance [11]).

Awareness of increased global warming makes it vital to analyse emissions of carbon dioxide for the DH systems, as has been done in studies by the author. Most municipal waste is of biological origin, but part is of fossil origin, such as plastic waste. The figure used for carbon dioxide emissions from municipal waste is around $90 \mathrm{~kg} / \mathrm{MWh}_{\mathrm{th}}$ (Swedish Association of Waste Management [12]), as compared to $280 \mathrm{~kg} / \mathrm{MWh}_{\text {th }}$ for oil. An important assumption when analyzing emissions of carbon dioxide is that locally produced electricity replaces electricity produced in coal condensing power plants, with emissions of carbon dioxide of around $950 \mathrm{~kg} / \mathrm{MWh}_{\mathrm{el}}$ (electrical efficiency $35 \%$, emissions from coal $\left.335 \mathrm{~kg} / \mathrm{MWh}_{\mathrm{th}}\right)$, which is the marginal producer of power in the European power system (Swedish Energy Agency [13]).

Other environmental issues associated with waste incineration include flue gas emissions and ashes from the incineration. The flue gases consist of hazardous substances such as heavy metals (e.g. lead, cadmium and mercury), dioxins, dust, and also substances that cause acidification. Today, waste incineration facilities have advanced flue gas cleaning systems and the emission of hazardous substances has decreased dramatically since the 1980s. However, dioxins and heavy metals end up in the flue gas ashes. These ashes constitute about $4 \%$ of the weight of the municipal waste and are classified as hazardous waste. These ashes have to be landfilled safely in order to prevent leakage. The bottom ash is about $19 \%$ of the weight of the municipal waste and is mostly landfilled, even if it might be used for road construction and covering landfills (Swedish Association of Waste Management [14]). In Holmgren and Amiri [15] some environmental effects other than carbon dioxide emissions are taken up. The debate around waste incineration has shifted from being a problem with emissions to whether it is suitable when aiming at a sustainable society with high resource efficiency. This question will be analysed to a certain extent in the study, where energy recovery and material recovery are compared in an energy efficiency perspective (Holmgren and Henning [16]), described in Section 4.4.

\subsection{Main policy instruments influencing waste incineration}

The main policy instruments affecting waste incineration include the introduction of a tax on landfill in 2000, at present $46.3 € /$ ton (Ministry of Finance [17]) and a ban on landfill of combustible waste from 2002, and from 2005 also of organic waste (Ministry of the Environment [18]). Carbon dioxide taxes for fossil fuels for heating purposes are around $0.1 € /$ ton, where heat from CHP and for industrial consumers have deducted levels (Ministry of Finance [19]). There is no carbon dioxide tax on waste. Electricity production is not taxed, but consumption is. The government has proposed a tax on incinerated waste (Ministry of Finance [11], further explained in Section 4.3. Policy instruments are examined in more detail in for example Holmgren [20]. 


\section{Results from case studies}

\subsection{Profitability of waste}

Earlier studies by the author on the role of waste as a fuel in DH systems concern the existing waste incineration plant in the city of Linköping (Holmgren and Bartlett [21], investment in a waste incineration plant in the city of Skövde (Holmgren and Gebremedhin [22]) and also additional investment in Linköping (Holmgren and Henning [16]). The studies show that in Skövde, the introduction of a waste incineration plant is profitable and in Linköping, investment in extended capacity is also profitable. What fuels the waste replaces depend on the configuration of the existing system. In Skövde it is mostly wood chip, since the new waste incineration plant replaces the wood chip boiler as base supplier of heat. In Linköping, there are large savings in biomass fuel, but the largest savings come from oil. The main measure to lower carbon dioxide emissions is to utilize CHP in the DH systems.

\subsection{The role of a DH system as user of various forms of waste heat}

DH systems have a big advantage since they can utilize heat that would otherwise be of limited use. This is considered in a study of the DH system in Göteborg, which uses various kinds of waste heat; from industries, waste incineration, and combined heat and power (Holmgren [20]). The base load of heat supply is from oil refineries in the vicinity of the city and heat from a wastefired CHP plant. Other heat sources are a natural gas fired CHP plant, heat pumps and hot water boilers utilising pellet, natural gas, and oil. The utility is currently investing in an additional natural gas-fired CHP plant, where the plant's profitability is dependent not only on electricity prices and policy instruments, but also on the utilisation of the heat in the DH system. The issue analysed is whether the various types of waste heat will "compete" with each other. An important assumption in this study is the realisation of an integrated European electricity market, which will mean higher electricity prices than are traditional in Sweden (Trygg and Karlsson [10]). The new natural gas fired CHP plant seems to be a beneficial investment, since the operating cost is reduced by $€ 150$ million over a ten-year period (no investment costs included), in light of these electricity prices. The conclusion is that there is space in the system for all these different waste heat sources, since the new CHP plant mainly affects production from hot water boilers and heat pumps and to a lesser degree waste heat from industries and the existing natural gas fired CHP plant.

Economic findings are that heat from waste incineration is advantageous and that a decrease in waste heat from industries would raise the operating cost considerably, even if more electricity were produced in that scenario and income generated from electricity sales is thus higher, due to increased use of more expensive heat supply from hot water boilers and heat pumps. The study also shows the importance of using the $\mathrm{DH}$ system for electricity production to control carbon dioxide emissions, since electricity produced locally can replace 
marginal power producers in continental Europe and therefore decrease carbon dioxide emissions. The sensitivity analysis shows the substantial impact of the assumed electricity price on the new CHP plant's operating time and hence its profitability.

The findings in this study contradict an earlier study that showed that increased waste incineration reduces electricity production since it removes the heat sink for CHP plants (Holmgren and Bartlett, [21]). An overall study of the DH systems in Sweden (Sahlin et al. [23]) also showed a decrease in electricity production due to greater waste incineration capacity. This shows that conditions vary in different $\mathrm{DH}$ systems.

\subsection{Analysis of two policy instruments}

Policy instruments have a substantial impact on the waste management and energy sectors. In Holmgren and Gebremedhin [22], the impact on the investment in a waste incineration plant of the introduction of a tax on incinerated waste is analysed. Tax levels of 11 and $€ 42.5$ per ton were analysed; these were the levels proposed in an earlier government investigation (Ministry of Finance, [24]). The conclusion was that at the tax level of $€ 11$ per ton, the investment was still profitable for the utility, but at the $€ 42.5$ per ton level, the investment was not profitable. The prerequisite for the results is naturally that the utility cannot raise the gate fee for receiving the waste. The results indicate, however, that at the higher tax level, other treatment options begin to be of interest. The recently proposed tax on incinerated waste (Ministry of Finance [11]) puts different tax levels on waste for CHP plants, around $€ 7$ per ton, and for hot water boilers around $€ 47$ per ton, in contrast to the above mentioned investigation.

The tax on incinerated waste is discussed in Holmgren [25], together with the green electricity certificate system. This system gives producers of electricity from renewable sources a certificate (Ministry of the Environment [26]). Consumers need certificates in relation to their consumption, thus creating a demand. Municipal waste is not included in the approved sources. The discussion concerns the difficulty in designing policy instruments for waste incineration due to its double function; as a waste treatment method and as a supplier of electricity and/or heat. The goals for waste management and energy system conflict, which makes it a complex affair to design policy instruments that affect waste incineration. In Holmgren [25] it is shown that when designing the proposed waste incineration tax, the energy system perspective was given prominence; the tax on incinerated waste had to harmonise with the taxation on other fuels used in the DH systems and incentives for CHP production were deemed important. No incentives were given to encourage more biological treatment and material recovery, except for plastic waste, even if that is a waste management goal. On the contrary, when designing the electricity certificate system and excluding municipal waste from approved sources, the perspective of waste management was put before the goals of the energy system. Including municipal waste would provide a greater incentive to produce more electricity in waste incineration plants but it would also steer waste of biological origin 
towards incineration, which would be inconsistent with Sweden's waste management goals, which state that at least $35 \%$ of biodegradable waste should be biologically treated by 2010 (Swedish Environmental Protection Agency [3].

\subsection{Comparison between energy recovery and material recovery from an energy efficiency viewpoint}

A study of the energy efficiency of material recovery and energy recovery is presented in Holmgren and Henning [16]. Material recovery saves virgin material, and also energy, since production processes that use recovered material are less energy intensive than processes that use virgin material, whereas energy recovery saves other fuels that differ from energy system to energy system. This study analyses two Swedish municipalities. The operation of the DH systems is optimized in two scenarios; with or without waste incineration. The study also shows the fuels used and the amount of electricity produced in the DH systems.

The fractions of glass and metal do not give any heat contribution when incinerated, but save varying amounts of energy when material recycled. The combustible fractions are more complicated to compare since they can be recovered in both ways. The study shows that even if there is a DH system able to utilise the heat, paper and plastics should be material recycled, whereas cardboard and biodegradable waste is more suited for energy recovery through waste incineration. These calculations were made on the assumption that biomass is a limited resource, and when saved eventually saves oil somewhere else in the system. Furthermore, in the calculations, electricity was multiplied by 2.5 based on the assumption that electricity is produced in a condensing plant with an electrical efficiency of 0.4 . That makes it extra important to produce CHP from waste incineration and also to consider how electricity intensive the various material production processes are.

\subsection{Internalising external costs of a DH system}

An external cost can be defined as "when the social or economic activities of one group of persons have an impact on another group and when that impact is not fully accounted, or compensated for, by the first group" (European Commission [27]). Electricity and heat production give raise to several negative external effects, such as climate change, acidification and health impacts (also positive external effects can occur, such as local employment). The costs for these effects should be internalized in the price for energy supply; otherwise a suboptimal consumption of energy occurs from a socio-economic perspective. The internalization can be made by for example taxes, subsides and fees. However, it is difficult to estimate the cost of external effects. Several attempts have been made to estimate the external costs of energy supply, where the ExternE project within the European Union is one of the most comprehensive. For a more thorough summary of external costs, see Carlsson [28].

A study is carried out to investigate whether external cost is a suitable method to assess the environmental impacts of waste incineration in a $\mathrm{DH}$ system (Holmgren and Amiri [15]). The aim is also to include more environmental 
effects, in addition to the emissions of carbon dioxide, than in earlier studies. The drawback is that only emissions to air is included in the external cost data, and the issues of residual products, such as ashes, and the efficient use of resources are not addressed; these are essential issues since the control of emissions to air has improved in recent years and has partly shifted the problems to the ashes. One major advantage is that it is a way to incorporate environmental effects in the existing systems and models and comparisons with for example environmental tax levels can easily be made. The main result from the study is increased CHP production in the DH system when including external costs, due to the assumption that this electricity replaces electricity produced in coal condensing power plants.

\section{Conclusion}

It is important to sort municipal waste in order to treat the different fractions of the waste according to the most preferable method for that fraction, and a variety of treatment methods are needed to avoid landfill. When choosing a waste treatment method, the connection to the technical energy system is important; whether it is possible to utilise the heat from the waste incineration, what other energy carriers are used, and so on. The structure of the energy system affects the consequences of choices made in the waste management system.

Waste management legislation banning landfill of combustible and organic waste and the taxes on landfill make waste competitive as a fuel in the analysed DH systems. Heat can be sold to DH customers, making incineration of waste competitive compared to other waste treatment methods. An additional effect is the favourable taxation of waste as a fuel and high taxes on fossil fuels. However, a tax on incinerated waste has recently been proposed which will alter the economic conditions for waste incineration.

Waste incineration can make it less viable to produce CHP in DH networks and this can be seen as a conflict between the need to treat waste in an acceptable way and the goal of more CHP production in the energy system. CHP is the main measure to decrease carbon dioxide emissions from $\mathrm{DH}$ systems on the assumption that locally produced electricity replaces electricity produced in coal condensing power plants.

Policy instruments have a significant impact on the systems. It is complicated to design policy instrument for waste incineration since the goals for waste management and the energy systems are conflicting.

The concept of external costs is one way to include environmental impact in calculations of profitability. One of its weaknesses, however, is that it is difficult to assess the cost of environmental impacts and the limited number of impacts included.

\section{Acknowledgments}

The work was carried out under the auspices of The Energy Systems Programme, which is financed by the Swedish Foundation for Strategic 
Research, the Swedish Energy Agency and Swedish Industry. The author is grateful to Maria Danestig for valuable comments on the paper.

\section{References}

[1] Henning, D. Cost minimisation for a local utility through CHP, heat storage and load management. International Journal of Energy Research 22:691-713; 1998.

[2] European Commission. Environment 2010: Our Future, Our Choices The Sixth Environmental Action Programme. (COM (2001) 31 final. Brussels, Belgium; 2001.

[3] Swedish Environmental Protection Agency. Strategi för hållbar avfallshantering. (Strategy for sustainable waste management, in Swedish), Stockholm, Sweden; 2005.

[4] Swedish Association of Waste Management. Svensk avfallshantering 2005 (Waste Management in Sweden 2005, in Swedish); 2005.

[5] Swedish Energy Agency. Energy in Sweden 2004. Eskilstuna, Sweden; 2004.

[6] Swedish Association of Waste Management. Avfallsförbränning. Utbyggnadsplaner, behov och brist. (Waste incineration. Expansion plans, capacity need and lack thereof, in Swedish) RVF-report 04:02; 2004.

[7] European Union. Council Directive 2004/8/EC on 11 February 2004 on the promotion of cogeneration based on a useful heat demand in the internal energy market and amending Directive 94/43/EEC. Brussels, Belgium; 2004.

[8] Swedish District Heating Association. Statistik 2003. (Statistics 2003, in Swedish) Sweden; 2005.

[9] Swedish District Heating Association. Kraftvärme och dess kopplingar till elcertifikatsystemet. (Combined heat and power and the connection to the electricity certificate system, in Swedish); 2005.

[10] Trygg, L. \& Karlsson, B.G. Industrial DSM in a deregulated European electricity market - a case study of 11 plants in Sweden. Energy Policy 33:1445-1459; 2005.

[11] Ministry of Finance. BRASkatt - beskattning av avfall som förbränns (GOODtax? - taxation on incinerated waste, in Swedish) SoU 2005:23. Stockholm, Sweden; 2005.

[12] Swedish Association of Waste Management. Förbränning av avfall. Utsläpp av växthusgaser jämfört med annan avfallsbehandling och annan energiproduktion (Waste incineration. Greenhouse gas emissions compared to other waste treatment and other energy production, in Swedish). RVF report 2003:12, Malmö, Sweden; 2003.

[13] Swedish Energy Agency. Marginal elproduktion och CO2-utsläpp i Sverige (Marginal electricity production and $\mathrm{CO} 2$-emissions in Sweden, in Swedish). ER 14:2002. Eskilstuna, Sweden; 2002.

[14] Swedish Association of Waste Management. Förbränning av avfall: En kunskapssammanställning om dioxiner, (Waste-to-energy: An inventory 
and review about dioxins, in Swedish) RVF-report 01:13, Swedish Association of Waste Management, Malmö, Sweden; 2001.

[15] Holmgren, K. \& Amiri, S. Internalising external costs of electricity and heat production in a municipal energy system - the case of waste incineration. Manuscript intended for journal publication.

[16] Holmgren, K. \& Henning, D. Comparison between material and energy recovery of municipal waste from an energy perspective. A study of two Swedish municipalities. Resources, Conservation and Recycling, 43:51$73 ; 2004$.

[17] Ministry of Finance. Lag (2005:962) om ändring i lagen (1999:673) om skatt på avfall (Law (2005:962) on changes in the law (199:673) governing waste tax, in Swedish); 2005.

[18] Ministry of the Environment. Förordning (2001:512) om deponering av avfall (Ordinance (2001:512) on landfill of waste, in Swedish); 2001

[19] Ministry of Finance. Lag om skatt på energi (1994:1776). (Law (1994:1776) on tax on energy, in Swedish), Stockholm, Sweden: 1994.

[20] Holmgren K. The role of a district heating network as a user of waste heat supply from various sources - the case of Göteborg. Accepted for publication in Applied Energy.

[21] Holmgren, K. \& Bartlett, M. Waste incineration in Swedish municipal energy systems - modelling the effects of various waste quantities in the city of Linköping. In: Afghan NH, Bogdan Z, Duic N. Editors. Sustainable development of energy, water and environment systems. Proceedings of the Conference, 2-7 June 2002, Dubrovnik, Croatia; 2004.

[22] Holmgren, K. \& Gebremedhin, A. Modelling a district heating system: introduction of waste incineration, policy instruments and co-operation with an industry. Energy Policy, 32:1807-1817; 2004.

[23] Sahlin, J., Knutsson, D. \& Ekvall, T. Effects of planned expansion of waste incineration in the Swedish district heating systems. Resources, Conservation and Recycling 41:279-292; 2004.

[24] Ministry of Finance. Skatt på avfall idag - och i framtiden (Tax on waste today - and in the future, in Swedish) SoU 2002:9, Stockholm, Sweden; 2002 .

[25] Holmgren, K. Energy recovery from waste incineration: linking the energy systems and waste management. Submitted for publication in Conservation and Recycling of Resources, Nova Publisher, Editor: Frank Columbus.

[26] Ministry of the Environment. Lag (2001:113) om elcertifikat. (Ordinance (2003:120) on electricity certificates, in Swedish), Stockholm, Sweden; 2001.

[27] European Commission. ExternE-Externalities of Energy. Vol.1-6, EUR 16520EN, Directorate-General XII, Luxembourg; 1995.

[28] Carlsson, A. Considering External Costs - Their Influence on Technical Measures in Energy Systems. Dissertation No 766, Linkoping Institute of Technology, Linkoping, Sweden; 2002. 